Jurnal Manajemen Kesehatan Yayasan RS.Dr.Soetomo Vol.4 No.1 April 2018

Print ISSN 2477-0140 Online ISSN 2581-219X

www.jurnal.stikes-yrsds.ac.id

\title{
Determinan Keberhasilan Pengobatan Multi Drug Therapy Pada Penderita
} Kusta Tipe Multibaciler

\section{Determinan of Success Multy Drug Therapy Treatment in the Patien Leprosy Type Multibaciler}

\author{
Muh. Zul Azhri Rustam \\ Sekolah Tinggi Ilmu Kesehatan Hang Tuah Surabaya \\ Email: zul.azhri@gmail.com
}

\begin{abstract}
ABSTRAK
Pengobatan MDT pada penderita kusta tipe Multibaciler (MB) adalah kegiatan menelan minum obat MDT secara intensif selama 12 bulan bagi penderita kusta tipe MB di Provinsi Sulawesi Selatan. Penyakit kusta tipe MB tidak dapat menyebabkan kematian, akan tetapi bila tidak menjalani pengobatan MDT menyebabkan kecacatan, masalah psikososial, stigma, dan penurunan produktivitas. Penelitian ini bertujuan untuk menganalisis faktor yang mempengaruhi keberhasilam pengobatan MDT pada penderita kusta tipe MB di Provinsi Sulawesi Selatan. Metode penelitian yang menggunakanCross Sectional. Teknik pengambilan sampel menggunakan Purposive Random Random Sampling untuk menentukan populasi penelitian, sehingga sampel yang diperoleh terdiri dari 47 sampel untuk Kota Makassar dan Kabupaten Pangkep. Hasil penelitian menggunakan ujistatistik regresi logistic pada variabel pelayanan kesehatan; akses pelayanan kesehatan tidak ada pengaruh terhadap kepatuhan minum obat MDT( $p$-value= $0,082>0,05)$, peran petugas kesehatan ada pengaruh terhadap kepatuhan minum obat MDT ( $p$-value $=0,003<0,05)$ dan ketersediaan obat ada pengaruh terhadap kepatuhan minum obat $\operatorname{MDT}(p$-value $=0,001<0,05)$, dan faktor kepatuhan minum obat ada pengaruh terhadap pengobatan MDT ( $p$-value $=0,000<0,05)$. Simpulan dari hasil penelitian inidiartikandenganpasien yang mempunyai peran petugas kesehatan yang baik dan ketersediaan obat MDT yang selalu tersedian disarana pelayanan kesehatan berpengaruhterhadapkepatuhanminumobat MDT
\end{abstract}

Kata Kunci: Release From Treatment, Multi Drug Therapy, KustaTipeMulti Baciler.

\begin{abstract}
MDT treatment in leprosy type Multibaciler (MB) is an intensive MDT intake activity for 12 months for MB leper patients in South Sulawesi Province.MB type leprosy disease can't cause death, but if not undergoing MDT treatment causes disability, psychosocial problems, stigma, and decreased productivity.This study aims to analyze the factors that influence the success of MDT treatment in MB type leprosy patients in South Sulawesi Province.The research method using Cross Sectional. The sampling technique using Purposive Random Sampling to determine subpopulation and Simple Random Sampling to determine the study population, the sample obtained consisted of 47 samples for Makassar and Pangkep.The result of the research used logistic regression statistic test on health service variable; access to health services has no effect on MDT adherence( $p$ value $=0,082>0,05$ ), the role of health workers has an influence on MDTadherence ( $p$ value $=0,003<0,05)$ availability of MDT drugshas an influence on MDTadherence ( $p$ value $=0,001<0,05)$, andDrug compliance factors have an effect on MDT treatment ( $p$ value $=0,000<0,05$ ). The conclusion of the results of this study is defined by the patients who have the role of a good health officer and the availability of MDTare always available health care services affect the adherence of MDT adherence.
\end{abstract}

Keyword: Release From Treatment, Multi Drug Therapy, Leprosy typeMulti Baciler, Adherence. 
Muh. Zul Azhri Rustam : Determinan Keberhasilan Pengobatan Multi Drug Therapy ....

\section{PENDAHULUAN}

Penyakit kusta adalah merupakan penyakit kronis yang disebabkan oleh infeksi Mycobacterium leprae (M.leprae)yang dapat menyerang saraf tepi, selanjutnya dapat menyerang kulit, mukosa, saluran pernafasan bagian atas, sistem tretikulo endothelial, mata, otot, tulang, dan testis, terkecuali pada susum dan saraf pusat.Penyakit kusta ini dapat menimbulkan masalahyang sangat kompleks baik dari segi medis maupun meluas sampai masalah sosial, ekonomi, budaya dan lain-lainnya (Amiruddin, 2003).

Upaya pencapaian eleminasi pada tahun 2000 secara global yang dilakukan oleh WHO (World Health Organization). Sejak saat itu Indonesia mengeluarkan program diantaranya adalah LEC (Leprosy Elemination Campaign) dan Sapel (Special Action for Elemination). Salah satu strategi yang dapat dilaksanakan untuk mencapai eleminasi kusta tersebut dengan meningkatkan ketersediaan dan keterjangkauan pengobatan MDT (Multi Drug Therapy) diseluruh puskesmas atau rumah sakit khusus kusta, meningkatkan kemampuan serta keterampilan petugas yang bertanggung jawab, meningkatkan kerjasama kemitraan dalam hal lintas program dan lintas sektor (Kemenkes RI,2012). Menurut penelitian Susanto Nugroho (2006) mengemukakan bahwa mayoritas tingkat ketaatan minum obat MDT pada penderita kusta yang telah mengalami tingkat kecataan tingkat 2 adalah penderita yang penderita yang tidak taat dalam minum obat MDT dengan tingkat presentase sebesar 82,8\% dibandingkan yang taat dalam hanya sebesar 17,6\%dan hal ini senada denganpernyataan Rachmat (2003) bahwa penyakit kusta sampai saat ini masih banyak penderita kusta yang mendapatkan pengobatan MDT (Multi Drug Therapy) ditemukan dalam kondisi yang sudah cacat. Akibat keterlambatan pengobatan MDT ini penyakit kusta terus dapat berjalan sehingga dapat kasus baru muncul.

Di beberapa daerah kawasan Indonesia, upaya pemberantasan kusta tipe MB masih berlangsung lamban. Hal ini disebabkan karena pengetahuan sosial ekonomi masyarakat, untuk masyarakat yang melakukan upaya pengobatan padahal pengobatan penyakit kusta tipe MB harus rutin dan teratur harus dituntaskan sampai penderita dinyatakan sembuh, memang memakan waktu cukup lama. Angka kesembuhan atau RFT adalah waktu dimulainya pemberian pengobatan MDT dan dimonitoring selama pengobatannya selama dalam kurun waktu 12 bulan untuk pasien kusta tipe MB, Dalam hal ini RFTdalam suatu daerah dinyatakan dengan Presentase. Di Provinsi Sulawesi Selatan angka RFT sangat bervariatif dari tahun 2010 terjadi penurunan sebesar 57,84\% pada tahun 2011 hal ini disebabkan karena dengan masih adanya beberapa daerah yang terpencil yang belum mendapatkan akses pelayanan kesehatan serta beberapa mobilitas 
penduduk yang cukup tinggi sehingga berpotensi lupa untuk melakukan pengobatan MDT. Pada tahun 2011 sampai 2013 terjadi peningkatan pengobatan disebabkan karena akses pelayanan kesehatan telah didapatkan beberapa daerah yang terpencil seperti pulaupulau kecil yang ada di sulawesi selatan (Dinkes Prov. Sulawesi Selatan, 2013).

Beberapa faktor yang dapat mempengaruhiny aantara lain adalah karakteristikre sponden, kepatuhan minum obat, pengetahuan, dukungan keluarga serta dari factor pelayanan kesehatan berupa jangkauan pelayanan kesehatan dan peran petugas kesehatan. (Panigoro, 2007). Mengingat tingkat RFT (release from treatment) penderita kusta yang ada di Provinsi Sulawesi Selatan masih dapat dikatakan belum mencapai target capaian pengabatan MDT yang telah ditentukan. Hal ini menarik dibahas dan diteliti untuk mempelajari factor penyebab pengobatan MDT yang ada di Provinsi Sulawesi Selatan.Tujuan penelitian ini untuk mengatahui factor dominan yang mempengaruhi terhadap keberhasilan pengobatan MDT pada penderita kusta tipe MB di Provinsi Sulawesi Selatan.

\section{METODE}

Jenis dalam penelitian ini merupakan penelitian epidemiologi observasional analitik dengan Rancang bangun menggunakan cross sectional (belah lintang) (Nasir A dan Muthith, 2011). Lokasi pada penelitian ini didua kota /kabupaten di Provinsi sulawesi Selatan. Populasi dalam penelitian ini adalah penderita kusta tipe MB yang telah menjalani pengobatan MDT yang tercatat di buku register kohort yang ada setiap puskesmas di kota makassar dan kabupaten pangkep tahun 2013. Besar sampel dalam penelitian ini adalah 47 orang dari di kota Makassar dan kabupaten pangkep jadi jumlah sampel secara keseluruhan adalah 94 orang. Teknik pengambilan sampel menggunankan purposive sampling untuk menentukan sub populasi di provinsi sulawesi selatan dan simple random sampling untuk menentukan jumlah sampel orang didua kota/kabupaten.

Variabel bebas dalam penelitian ini adalah faktor perilaku; pengetahuan, dukungan keluarga dan faktor pelayanan kesehatan; akses pelayanan kesehatan, peran petugas kesehatan dan ketersediaan obat.Sedangkan variabel tergantungnya adalahkepatuhan minum obat pada pengobatan MDT. Pengumpulan data langsung dari hasil wawancara terhadap responden menggunakan kuesioner. Analisis data dengan menggunakan uji regresi logistik sederhana untuk melihat pengaruh variabel independent dengan skala data nominal terhadap variabel dependent yang berbentuk nominal dan analisis regresi logistik ganda untuk menguji variabel independen terhadap variabel 
Muh. Zul Azhri Rustam : Determinan Keberhasilan Pengobatan Multi Drug Therapy ....

dependen secara bersamaan. Hasil sig (p) dibandingkan dengan $\alpha=0,05$, apabila $p<\alpha$ maka artinya ada pengaruh variabel independen terhadap variabel dependen.

HASIL

Adapun gambaran hasil penelitian diperoleh melalui penjelasan tabel 1 sebagai berikut :

Tabel 1 Distribusi Karakteristik Responden Berdasarkan: Umur, Jenis Kelamin, Tingkat Pendidikan, Pekerjaan dan Pendapatan Terhadap Kepatuhan Minum Obat di Provinsi Sulawesi Selatan.

\begin{tabular}{|c|c|c|c|c|}
\hline \multirow[b]{2}{*}{ No } & \multirow[b]{2}{*}{ Variabel } & \multicolumn{3}{|c|}{ Kepatuhan Minum Obat } \\
\hline & & Patuh (\%) & Tidak Patuh (\%) & $\begin{array}{c}\text { Total } \\
(\%)\end{array}$ \\
\hline \multirow[t]{5}{*}{1.} & Umur & & & \\
\hline & $17-28$ tahun & $25(51,0)$ & $24(49,0)$ & $49(100)$ \\
\hline & $29-40$ tahun & $15(62,5)$ & $9(37,5)$ & $24(100)$ \\
\hline & $>41$ tahun & $17(81,0)$ & $4(19,0)$ & $21(100)$ \\
\hline & Total & $57(60,6)$ & $37(39,4)$ & $94(100)$ \\
\hline \multirow[t]{4}{*}{2.} & Jenis Kelamin & & & \\
\hline & Perempuan & $21(63,6)$ & $12(36,4)$ & $33(100)$ \\
\hline & Laki laki & $36(59,0)$ & $25(41,0)$ & $61(100)$ \\
\hline & Total & $57(60,6)$ & $37(39,4)$ & $94(100)$ \\
\hline \multirow[t]{7}{*}{3.} & Pendidikan & & & \\
\hline & PT & $7(77,8)$ & $2(22,2)$ & $9(100)$ \\
\hline & SMA & $13(61,9)$ & $8(38,1)$ & $21(100)$ \\
\hline & SMP & $7(58,3)$ & $5(41,7)$ & $12(100)$ \\
\hline & SD & $25(67,6)$ & $12(32,4)$ & $37(100)$ \\
\hline & Tidak Sekolah & $5(33,3)$ & $10(66,7)$ & $15(100)$ \\
\hline & Total & $57(60,6)$ & $37(39,4)$ & $94(100)$ \\
\hline \multirow[t]{7}{*}{4.} & Pekerjaan & & & \\
\hline & PNS/TNI/Polri & $3(75,0)$ & $1(25,0)$ & $4(100)$ \\
\hline & Wiraswasta & $18(33,7)$ & $9(33,3)$ & $27(100)$ \\
\hline & Petani & $2(25,0)$ & $6(75,0)$ & $8(100)$ \\
\hline & Buruh & $25(58,0)$ & $18(41,0)$ & $43(100)$ \\
\hline & IRT & $9(75,0)$ & $3(25,0)$ & $12(100)$ \\
\hline & Total & $57(60,6)$ & $37(39,4)$ & $94(100)$ \\
\hline
\end{tabular}

Pada tabel 1 di peroleh bahwa mayoritas responden yang patuh minum obat adalah kelompok umur 17 - 28 tahun, jenis kelamin laki-laki, berpendidikan Sekolah Dasar, pekerjaan sebagai buruh.. 
Tabel 2 DistribusiKepatuhan Minum Obat Berdasarkan Tingkat Pengetahuan Di Provinsi Sulawesi Selatan

\begin{tabular}{lcccc}
\hline \multirow{2}{*}{ Pengetahuan } & \multicolumn{3}{c}{ Kepatuhan Minum Obat } & \multirow{2}{*}{ Nilai- $p$} \\
& Patuh(\%) & Tidak Patuh (\%) & Total (\%) & \\
\hline Baik & $46(79,3)$ & $12(20,7)$ & $58(100)$ & \multirow{2}{*}{0,000} \\
Kurang & $11(30,6)$ & $25(69,4)$ & $36(100)$ & \\
Total & $57(60,6)$ & $37(39,4)$ & $94(100)$ & \\
\hline
\end{tabular}

Hasil analisis pada tabel 2 diatas menunjukkan bahwa terdapat hubungan antara pengetahuan terhadap kepatuhan minum obat, dan mayoritas responden dengan tingkat pengetahuan baik patuh minum obat, sedangkan responden dengan tingkat pengetahuan kurang tidak patuh minum obat.

Tabel 3 DistribusiKepatuhan Minum Obat Berdasarkan Dukungan Keluarga Provinsi Sulawesi Selatan

\begin{tabular}{|c|c|c|c|c|}
\hline \multirow{2}{*}{$\begin{array}{l}\text { Dukungan } \\
\text { Keluarga }\end{array}$} & \multicolumn{3}{|c|}{ Kepatuhan Minum Obat } & \multirow{2}{*}{ Nilai- $p$} \\
\hline & Patuh(\%) & Tidak Patuh (\%) & Total (\%) & \\
\hline Baik & $30(68,2)$ & $14(31,8)$ & 44 (100) & \\
\hline Kurang Baik & $27(50,4)$ & $23(46,0)$ & 50 (100) & 0,160 \\
\hline Total & $57(60,6)$ & $37(39,4)$ & $94(100)$ & \\
\hline
\end{tabular}

Hasil analisis pada tabel 3diatas menunjukkan bahwa tidak terdapat hubungan antara dukungan keluarga terhadap kepatuhan minum obat, dan mayoritas responden yang mendapatkan dukungan keluarga yang baik patuh minum obat, sedangkan responden yang mendapatkan dukungan keluarga yang kurang baik tidak patuh minum obat.

Tabel 4 DistribusiKepatuhan Minum Obat Berdasarkan Akses Pelayanan Kesehatan Di Provinsi Sulawesi Selatan

\begin{tabular}{lcccc}
\hline Akses Pelayanan & \multicolumn{3}{c}{ Kepatuhan Minum Obat } & \multirow{2}{*}{ Nilai- $p$} \\
Kesehatan & Patuh(\%) & Tidak Patuh (\%) & Total (\%) & \\
\hline Mudah & $38(67,9)$ & $18(32,1)$ & $56(100)$ & \\
Sulit & $19(50,0)$ & $19(50,0)$ & $38(100)$ & 0,082 \\
Total & $57(60,6)$ & $37(39,4)$ & $94(100)$ & \\
\hline
\end{tabular}

Hasil analisis pada tabel 4 diatas menunjukkan bahwa tidak terdapat hubungan antara akses pelayanan kesehatan terhadap kepatuhan minum obat, dan mayoritas responden yang memiliki akses pelayanan kesehatan yang mudah ataupun sulit dapat patuh minum obat. 
Muh. Zul Azhri Rustam : Determinan Keberhasilan Pengobatan Multi Drug Therapy ....

Tabel 5 DistribusiKepatuhan Minum Obat Berdasarkan Peran Petugas Kesehatan Di Provinsi Sulawesi Selatan

\begin{tabular}{lcccc}
\hline $\begin{array}{l}\text { Peran Petugas } \\
\text { Kesehatan }\end{array}$ & Patuh(\%) & Tepatuhan Minum Obat & \multirow{2}{*}{ Nilai- $p$} \\
\hline Baik & $48(69,6)$ & $21(30,4)$ & $69(100)$ & \\
Kurang Baik & $9(36,0)$ & $16(64,0)$ & $25(100)$ & 0,003 \\
Total & $57(60,6)$ & $37(39,4)$ & $94(100)$ & \\
\hline
\end{tabular}

Hasil analisis pada tabel 5 menunjukkan bahwa terdapat hubungan antara peran petugas kesehatan terhadap kepatuhan minum obat dan mayoritas responden yang mempunyai peran patugas kesehatan yang baik dapat patuh minum obat, sedangkan untuk responden yang mempunyai peran petugas kesehatan yang kurang baik dapat tidak patuh minum obat.

Tabel 6 DistribusiPengobatan MDT Berdasarkan Kepatuhan Minum Obat Di Provinsi Sulawesi Selatan

\begin{tabular}{lcccc}
\hline $\begin{array}{l}\text { Kepatuhan } \\
\text { minum obat }\end{array}$ & RFT(\%) & $\begin{array}{c}\text { Pengobatan MDT } \\
\text { Non RFT }(\%)\end{array}$ & Total $(\%)$ & Nilai- $p$ \\
\hline Patuh & $56(98,2)$ & $1(1,8)$ & $57(100)$ & \\
Tidak Patuh & $7(18,9)$ & $30(81,1)$ & $37(100)$ & 0,001 \\
Total & $63(67,0)$ & $31(33,0)$ & $94(100)$ & \\
\hline
\end{tabular}

Hasil analisis pada tabel 6 menunjukkan bahwa artinya terdapat hubungan antara kepatuhan minum obat terhadap pengobatan MDT. Mayoritas responden yang patuh minum obat pengobatan MDT dapat dinyatakan RFT, sedangkan responden yang tidak patuh minum obat non RTF.

\section{PEMBAHASAN}

Pada tabel 2 Akses pelayanan kesehatan diartikan sebagai jarak tempat tinggal penderita, waktu yang ditempuh, adanya alat transportasi dan kemudahan untuk menjangkau sarana pelayanan kesehatan. Berdasarkan hasil penelitian maka diketahui bahwa tidak ada pengaruh antara akses pelayanan kesehatan terhadap kepatuhan minum obat MDT. Dikarenakan ada beberapa responden yang jarak tempat tinggal lebih dari jarak tempuhnya 45 menit dari tempat pelayanan kesehatan. Hal ini juga dapat disebabkan karena masih adanya stigma negatif dari masyarakat, salah satunya responden yang menderita kusta tipe MB untuk mengambil obat ke tempat pelayan kesehatan menggunakan alat transportasi umum kadang tidak diberikan tumpangan oleh sopir angkutan umum dikarenankan takut akan penyakit yang diderita responden.

Hal ini sejalan dengan hasil penelitian yang dilakukan oleh Pireno (2002) di Yogyakarta diketahui bahwa tidak ada hubungan antara jarak pelayanan kesehatan 
dengan pengabatan kusta secara teratur dengan penderita kusta. Hal ini mungkin dapat disebabkan oleh karena adanya penderita semakin malas untuk datang ke tempat pelayanan kesehatan tersebut karena jarak tempat tinggal mereka dari tempat pelayan kesehatan makin jauh dan sulit untuk dijangkau.

Semakin dekatnya tempat pelayanan kesehatan akan semakin memudahkan akses pelayanan kesehatan terhadap penderita kusta tipe MB dan sebaliknya semakin jauh tempat pelayanan kesehatan akan menyulitkan penderita untuk berobat secara teratur ke tempat pelayanan kesehatan. Pemberian obat MDT untuk penderita kusta tipe MB yang bertempat tinggal diluar jangkauan petugas kesehatan akan menghasilkan kegagalan yang cukup tinggi (Manik et al, 1989).

Pelayanan yang baik dari petugas kesehatan dapat menyebabkan orang berperilaku positif. Perilaku petugas kesehatan yang ramah dapat mengobati pasien terlebih dahulu tanpa harus telalu lama untuk menunggu dan mengambil obat, maka penderita merasa dihargai untuk datang berobat ke puskesmas. Kadang-kadang kebanyakan orang datang ke tenaga kesehatan, karena hampir semua orang mempunyai keluhan yang menakutkan tentang kunjungan pada petugas kesehatan (Smet, 1994). Berdasarkan hasil penelitian ini terdapat pengaruh pengaruh antara peran petugas kesehatan terhadap kepatuhan minum obat MDT.

Hal ini disebabkan karena peran petugas kesehatan mampu untuk memberikan informasi yang baik tentang lama pengobatan, aturan minum obat, informasi kusta dengan kalimat-kalimat yang sesuai dengan tingkat pendidikan responden sehingga responden dapat memahami informasi dari petugas kesehatan, dan petugas kesehatan memberikan fasilitas transportasi khusus untuk penderita kusta tipe MB khususnya pada penderita kusta yang telah mengalami kecacatan dan belum mengalami cacat guna untuk pengobatan MDT. Hasil penelitian ini sejalan dengan penelitian yang dilakukan oleh Masduki (1993) di Kabupaten Kuningan bahwa peran petugas kesehatan mempunyai hubungan yang bermakna terhadap keteraturan berobatat. Sedangkan hasil penelitian yang dilakukan oleh Fenty Anggiawati (2010) yang mengatakan bahwa peran petugas kesehatan tidak berhubungan keteraturan berobat yang ada hubungan dengan hasil pengobatan pada penderita kusta.

Ketersediaan obat merupakan bagian dari tujuan utama pada pengelolan MDT dengan tujuan adalah memastikan ketersediaan obat bagi pasien tepat waktu di Puskesmas yang diberikan secara gratis. Berdasarkan hasil penelitian menunjukkan bahwa sebagian besar obat selalu tersedia di puskesmas dari pada obat kadang tersedia di 
puskesmas. Hasil penelitian menunjukkan bahwa ada pengaruh antara ketersediaan obat terhadap kepatuhan minum obat MDT. Disebabkan karenkan beberapa puskesmas dalam pengajuan stock ke dinas kesehatan kesehatan pengobatan dinilai tepat waktu. Obat MDT yang ada di puskesmas dapat tersedia selalu sehingga apabila responden mengambil obat MDT tidak dapat diberikan tepat waktu dan tidak dijanjikan oleh petugas kesehatan. Hasil penelitian ini tidak sejalan dengan penelitian yang dilakukan oleh Harjo (2010) yang menyatakan bahwa terdapat hubungan yang bermakna antara ketersediaan obat di puskesmas terhadap ketidaketeraturan berobat pada penderita kusta di Kabupaten Majalengka.

Kepatuhan minum obat secara operasional disebutkan adalah kegiatan penderita menelan minum obat MDT pada waktu yang tepat dan jumlah tablet yang telah ditentukan sesuai dengan aturan dokter secara teratur. Berdasarkan hasil penelitian diperoleh terdapat pengaruh antara kepatuhan minum obat terhadap pengobatan MDT. Hal ini disebabkan karena dari responden dalam penelitian ini mayoritas terdapat jenis kelamin laki-laki yang penderita kustatipe MB yang berkerja seperti biasa akan dapat termotivasi untuk patuh minum obat demi kesembuhannya karena pekerjaanya merupakan sumber dari pencahariaanya, sumber untuk memberikan nafkah dan berguna bagi keluarga walaupun kondisi tubuh mereka menderita penyakit kusta tipe MB dan petugas kesehatan atau wasor kusta memonitoring waktu pengambilan obat MDT tiap bulannya selama masa pengobatan.

Hasil tersebut sejalan dengan penelitian Fenty Anggiriawati (2010) yang menyatakan bahwa ada hubungan keteraturan pengobatan dengan kesembuhan pada penderita kusta tipe MB. Berdasarkan hasil penelitian tersebut dapat artikan sebagai seseorang dengan mempunyai peran petugas kesehatan yang baik dan ketersediaan obat MDT yang selalu tersedian di sarana pelayanan kesehatan mempunyai nilai probabilitas untuk patuh minum obat sebesar $89 \%$.

\section{SIMPULAN}

Berdasarkan uraian hasil diskusi diatas dapat disimpulkan bahwa Hasil penelitian ini diperoleh hasil karakteristik dari penderita kusta tipe MB terhadap kepatuhan minum obat MDT yaitu, mayoritas kelompok umur produktif yakni kelompok umur kategori 1 (17 - 28 tahun) berjenis kelamin laki-laki, mempunyai tingkat pendidikan SD, dan pekerjaannya sebagian besar adalah buruh serta mempunyai pendapatan di bawah UMR. 
Faktor pelayanan kesehatan terdapat pengaruh antara peran petugas kesehatan dan ketersediaan obat di puskesmas terhadap kepatuhan mium obat MDT, sedangkan akses pelayanan kesehatan tidak terdapat pengaruh antara kepatuhan minum obat MDT pada penderita kusta tipe MB di Provinsi Sulawesi Selatan. Faktor kepatuhan minum obat terdapat pengaruh antara pengobatan MDT (Multi Drug Therapy) pada penderita kusta tipe MB di Provinsi Sulawesi Selatan.Berdasarkan hasil penelitian tersebut dapat artikan sebagai seseorang dengan mempunyai peran petugas kesehatan yang baik dan ketersediaan obat MDT yang selalu tersedian di sarana pelayanan kesehatan mempunyai nilai probabilitas untuk patuh minum obat sebesar $89 \%$.

\section{UCAPAN TERIMA KASIH}

Penulis mengucapkan ucapan terima kasih kepada pihak Kepala Dinas Kesehatan Provinsi Sulawesi Selatan yang telah banyak membantu memberikan bantuan data dan petugas lapangan dalam pengumpulan data sehingga penelitian ini dapat terselesaikan dengan lancar dan baik.

\section{DAFTAR PUSTAKA}

Agustina, F. A. (n.d.). Analisis Hubungan Faktor-Faktor Yang Menentukan Kesembuhan kusta (Study Kasus Di Puskesmas Kundurun Dan Puskesmas Banjarejo) Di Kabupten Blora. Retrieved from http://eprint.undip.ac.id/35269.

Amiruddin, M.D., A. A. . (2003). Penyakit Kusta Pada Anak Di Poliklinik Kulit Dan Kelamin RSUD Dr Wahidin Sudirohusodo. Jurnal Medika Nusantara, (2), 40-42.

Dinkes Prov Sul-Sel. (2013). Profil Kesehatan Provinsi Sulawesi Selatan Tahun 2012. Makassar.

Harjo. (2000). Faktor-Faktor Yang Berhubungan Dengan Ketidakteraturan Berobat Penderita Kusta Di Kabupaten Majalengka Tahun 1998 - 2000. Universitas Indonesia. Retrieved from http://www.digilib.ui.ac.id/opac/92369 Sitasi 14 Juli 2014

Kemenkes RI. (2012a). Pedoman Nasional Program Pengendalian Penyakit Kusta. Jakarta.

Kemenkes RI. (2012b). Profil Kesehatan Republik Indonesia tahun 2011. Jakarta.

Manik, S.N., Wartono, R., dan Agusni, L. (1989). Pengobatan MDT Multibaciller pada penderita kusta di Poli RSUD Dr. Sutomo Surabaya. Kumpulan Kongres PDA VI Ke VI, 147-152.

Masduki. (1993). Faktor Faktor Yang Mempengaruhi Perilaku Kepatuhan Berobat Penderita Kusta Di Kabupaten Kuningan Jawa Barat. Retrieved from http://digilib.litbang.depkes.go.id

Nasir Abd et al. (2011). Buku Ajar: Metodologi Penelitian Kesehatan konsep pembuatan Karya Tulis dan Thesis untuk Mahasiswa Kesehatan. 
Muh. Zul Azhri Rustam : Determinan Keberhasilan Pengobatan Multi Drug Therapy ....

Yogyakarta: Nuha Medika Yogyakarta.

Panigoro Sabri. (2007). Beberapa Faktor yang mempengaruhi keteraturan berobat penderita kusta di Provinsi Gorontalo. Universitas Gadjahmada Yogyakarta.

Pireno Budi. (2003). Evaluasi Penemuan Penderita Kusta Baru Dan FaktorFaktor Penentu Ketidakteraturan Berobat Penderita Kusta Di Yogyjakarta. Universitas Gadjahmada.

Rachmad H. (2003). Kusta: Program Pemberantasan Penyakit Kusta di Indonesia. Jakarta: Balai Penerbit FKUI.

Smet B. (1994). Psikologi Kesehatan. Jakarta: PT Grasindo.

Susanto Nugroho. (2006). Faktor yang berhubungan dengan tingkat kecatatan penderita kusta (kajian di kabupaten sukoharjo). Universitas Gadjah Mada. 